\title{
The novelties in the legislation of the Russian Federation on public financial control
}

\section{Introduction}

In 2013, the Russian legislation on state financial control underwent significant changes. However, legislative reform was launched in 2001 with the adoption of the Federal Law No. 6-FZ "On General Principles of Organization and Activities of the Control and Accounting Institutions of Constituent Entities of the Russian Federation and $\mathrm{Mu}-$ nicipal Entities" ${ }^{1}$. Prior to that, the issues of organization and activity of control and accounting bodies remained unregulated at the federal level in the Russian Federation. The picture of regional financial control was "colorful", and in a number of cases it even had a negative impact on the effectiveness of control measures².

The Russian Federation is a federal state, and in conformity with Article 65 of the Constitution of the Russian Federation ${ }^{3}$ (hereinafter the Constitution of RF), it includes the following constituent entities: republics, territories, regions, cities of federal importance, autonomous region, autonomous areas - 83 constituent entities of the Russian Federation (hereinafter, regions) in total. In compliance with Part 2 of Article 76 of the Constitution of RF on issues of joint jurisdiction of the Russian Federation and the regions, a framework of federal laws shall be issued and the laws and other normative acts of the regions shall be adopted according to them. In addition to that, the laws and other normative acts adopted in conformity with the abovementioned constitutional

1 Collection of legislation of the Russain Federation, 2011, No. 7, Art. 903.

2 See more detail: A. N. Kozyrin. Legal regulation of the organization and activities of control and audit bodies: scientific and practical commentary of Article 2 of the Federal Law On General Principles of Organization and Activities of the Control and Accounting Institutions of Constituent Entities of the Russian Federation and Municipal Entities, "Reforms and the Law" vol. 4, 2011; A. A. Yalbulganov, Control counting bodies and the implementation of the external state and municipal financial control, "Reforms and the Law" vol. 1, 2012

3 The Constitution of the Russian Federation (adopted at National Voting on December 12, 1993), Collection of legislation of the Russian Federation, 2009, No. 4, Art. 445. 
provision may not contradict the federal laws. In the case of a contradiction between a federal law and a normative act issued in the Russian Federation, the federal law shall be applied (Part 6 of Article 76 of Constitution of RF). According to Part 5 of Article 101 of the Constitution of RF, in order to execute control over the implementation of the federal budget, the Council of the Federation and the State Duma ${ }^{4}$ created the Accounts Chamber of the Russian Federation, the composition and rules of work of which are fixed by federal law.

The new Federal Law of April 5, 2013 "On the Accounts Chamber of the Russian Federation" 5 significantly expanded the powers of the control agency. This Federal Law clearly indicates the mechanisms of legal influence on the participants in financial control relations, with the purpose of executing the rights ${ }^{6}$ delegated to the Accounts Chamber. The Federal Law of May 7, 2013 "On Parliamentary Control" indicates the Accounts Chamber as a parliamentary control body and lays down its status as a constitutional body executing state financial control.

And, finally, Section 9 of the Budget Code of the Russian Federation (hereinafter, $\mathrm{BC}$ of RF) "State and Municipal Financial Control" ${ }^{8}$ was adopted with new wording and establishes a new conceptual approach to the organization of budgetary control. The amendments apply to organizational and legal fundamentals of exercising state and municipal financial control (hereinafter, public financial control) with incrementing anti-corruption tasks, and to the issue of vesting the regional financial bodies with the authority to exercise internal public financial control in the area of budgetary legal relationships, etc.

The Russian scholarly community accepted the ambiguous legislative reform of state and municipal financial control. For example, Prof. V. P. Belyaev considers that there are no differences between the concept of control and supervision. Consequently, the distinction between control and supervision of financial activities remains problematic. Supervisory activities are conducted by the prosecution office and in his opinion it is not included in any of the branches of power. He emphasizes that the public prosecutor's supervision, in comparison with state control, covers all the areas of public relations ${ }^{9}$.

4 According to the Constitution of RF, the parliament of the Russian Federation is the Federal Assembly that is the representative and legislative body of the Russian Federation. The Federal Assembly consists of two chambers - the Council of the Federation and the State Duma.

5 Collection of legislation of the Russian Federation, 2013, No. 14, Art. 1649.

6 The Federal Law of January 11,1995, No. 4-FZ, Collection of legislation of the Russian Federation, 1995, No.3, Art. 167.

7 Collection of legislation of the Russian Federation, 2013, No. 19, Art. 2304.

8 The Federal Law of July 23, 2013 No. 252-FZ "On amending the Budget Code of the Russian Federation and certain legislative acts of the Russian Federation", Collection of legislation of the Russian Federation, 2013, No. 31, Art. 4191.

9 V. P. Belyaev, Control and supervision legal activity: about distinction of notions, „Law and politics” vol. 2, 2014, p. 248. 
Prof. A. N. Kozyrin writes that the relevant legislative changes should not remain merely on paper but should be put into action. In this case they will contribute to the optimization of public financial control and improve its effectiveness ${ }^{10}$.

In support of the reform, Prof. R. E. Artyukhin notes that the issues of improvement of the legal framework and the methods of state financial control are very important. This is determined by active implementation of measures against corruption in the public sector and procurement, as the prevention of violations in these areas depends on the effectiveness of internal and external state financial control. According to him, the strengthening of control is justified due to the transition of the Russian Federation to a programmed budget, and is consistent with the objectives of public policy ${ }^{11}$.

\section{The main objectives of the Federal Law No. 6-FZ “On General Principles of Organization and Activities of the Control and Accounting Institutions of the Constituent Entities of the Russian Federation and Municipal Entities"}

The Federal Law No. 6-FZ determines the peculiarities of the status of regional control and accounting bodies as implementing agencies of state financial control.

A regional control and accounting institution of the Russian Federation is an independent state body of a region of the Russian Federation, as evidenced by certain provisions of the Federal Law No.6-FZ, vesting the mentioned bodies with organizational, functional, financial and administrative autonomy.

The independence of a regional control and accounting body shall be guaranteed by the system of norms governing the procedure for appointment and termination of the authorities of the Chairman, Deputy Chairman and auditors of the body. The organizational and functional independence of the control and accounting body of a region is determined by the nature of its objectives and the scope of its representative powers. One of the most important guarantees of independence of a regional control and accounting body is its financial autonomy, determined in the Federal Law No. 6-FZ.

The funds intended for financial support of a regional control and accounting body shall be provided for in a regional budget as a separate source.

The control and accounting body of a region, being a permanent body of external public financial control, exercises control over the execution of the regional budget and the budget of public extra-budgetary funds of a territory, over the legality and efficiency of use of inter-budget transfers allocated from regional budgets to the budgets of municipal entities, as well as over local budget execution in cases determined by the BC of RF.

10 A. N. Kozyrin, Legal basis of state and municipal financial control, „Reform and law” vol.1, 2014, p. 75. 11 R. E Artyukhin, State financial control: contemporary legal regulation, Moscow 2014, p. 3. 
Along with that, a control and accounting institution of a constituent entity of the Russian Federation exercises control over the legality and efficiency of use of regional budgetary funds, the public extra-budgetary funds of territories and other sources determined by the legislation of the Russian Federation. It is also authorized to audit the effectiveness of taxes and other exemptions and privileges, budgetary credits funded by the means of regional budgets, the legitimacy of issuing state guarantees and other forms of securing the performance of obligations on transactions conducted by legal entities and individual entrepreneurs involving the funds of regional budgets and property in the state ownership of a region.

In the course of executing its expert and analytical powers, the control and accounting institution of a region performs:

- Expertise of draft laws on the budgets of a region and draft laws on the budgets of territories' extra-budgetary funds ;

- Financial and economic expertise of the draft laws of a region and normative legal acts of regional public bodies of the Russian Federation (including the validity of financial and economic justifications) in relation to the expenditure obligations of a region, as well as the state programs of regions;

- Analysis of the budget process of a region and the development of proposals aimed at its improvement;

- External audit of the annual budget execution report of a region, the annual report on the execution of a state territorial extra-budgetary fund.

Within the framework of exercising informational powers, the control and accounting institution of a region prepares information on the course of regional budget performance and execution of the state's territorial extra-budgetary funds, on the results of the control and expert and analytical activities, as well as submitting this information to the legislative (representative) state regional authority and to the supreme authority of the region (Head of the supreme state executive body of the constituent entity of the Russian Federation).

Based on the results of the executed control measures, control and accounting institutions have the right to deliver to the state and regional authorities, inspected organizations and their heads, representations for undertaking measures for the elimination of revealed violations and discrepancies, the prevention of damage to a region of the Russian Federation, the taking of legal steps against officials found to be violating legislation, as well as measures on restraining, eliminating and preventing violations.

It should be noted that the heads of inspected objects must create appropriate conditions for the work of the officials of the control and accounting bodies conducting inspections. They are to provide them with the necessary office accommodation, requested information and documentation, and they should prepare necessary notes and references, ensure free access to the workplace and the inspected property. 
Representation of the control and accounting institution of a region is a document containing binding requirements of the control and accounting body, addressed to the heads of the inspected objects for consideration and the undertaking of measures to eliminate revealed violations and prevent damage to the constituent entity of the Russian Federation, municipal entity, or compensate for the damage done, take legal steps against the officials found to be violating legislation and measures to deter, eliminate and prevent violations.

Should any breaches at the inspected objects be revealed which need to be immediately eliminated and prevented, the control and accounting institutions have the right to issue a mandatory ordinance. An ordinance shall also be issued in cases where control measures exercised by the officials of the control and accounting bodies are impeded. The control and accounting institutions can issue an ordinance to federal and regional executive bodies, local self-governance bodies and municipal authorities, and to the management of the inspected enterprises, institutions and organizations.

An ordinance of a control and accounting institution shall indicate specific grounds for its issuance, specific violations committed, requirements for undertaking measures to eliminate them, and the term of an order fulfillment. In accordance with the Federal Law No. 6-FZ, an ordinance of a control and accounting institution must be fulfilled within the term stated in the document. Non-compliance or improper compliance with an ordinance of a control and accounting institution shall entail responsibility prescribed by the legislation of the Russian Federation and (or) regional legislation. For execution of the ordinance, the time period shall be determined as reasonable for the inspected entity to execute prescribed activities or terminating activities depending on the circumstances that served as grounds for the issuance of an ordinance.

Representations and ordinances are the apogee of the control activities of the control and accounting institutions. They are both the result of the institutions' activity and an opportunity to enforce violators of financial discipline to eliminate the revealed breaches. It seems to us that the existence of an effective system of control and accounting institutions is an important guarantee of facilitation of regional reforms in the Russian Federation.

\section{The new Federal Law “On the Accounts Chamber of the Russian Federation" and development of external public financial control}

Compared to the previous Federal Law on the Accounts Chamber of 1995, the new law obtained solid legal and technical characteristics. The subject of regulation is relations arising in the process of implementation by the Accounts Chamber of its authorities. The Accounts Chamber of the Russian Federation is the standing supreme body of external public audit (control). Within its competence it has the right to exercise control 
over the formation, administration and disposal of funds of the federal budget, extrabudgetary funds, the federal property (hereinafter, federal resources) and other resources.

The new law has been developed from the years of experience gained by the Accounts Chamber of the Russian Federation and is aimed at elaborating new approaches to the performance of external public auditing (control) in the Russian Federation, taking into account the need to enhance the role of the Chamber as a tool of parliamentary and public control and to strengthen anti-corruption measures.

Considering the necessity of bringing the norms of law into the sphere of external public auditing (control), in compliance with international norms and definitions, the law includes a number of new concepts conforming to the powers of the Accounts Chamber of the Russian Federation. This is aimed at ensuring effective implementation of auditing, expertise, analysis and provision of information, along with other activities of the Chamber. The mentioned activities are being carried out in the form of financial audits, strategic audits, performance audits, audits of federal programs (projects), audits of national and international investment programs, federal information technologies (projects and systems) and contract audits.

For instance, a financial audit (control) is exercised with the purpose of examining the validity of financial operations, budget accounting, budgetary and other reporting, the targeted use of federal and other resources, while a performance audit is applied in order to determine the effectiveness of the use of resources .

To ensure due implementation of the abovementioned auditing activities, the scope of objectives of the Accounts Chamber was significantly expanded, including, namely:

- Support for the accomplishment of the strategic goals of the socio-economic development of the Russian Federation in terms of efficiency and effectiveness;

- Development of the auditing (control) capacities and methods for assessing the performance of procedures of formation, administration and use of federal and other resources, including the selection and evaluation of key national indicators, and indicators of the socio-economic development of the Russian Federation, and their compliance with the provisions of the normative legal acts of the Russian Federation;

- Analysis, within its competence, of the efficiency of administration and use of federal and other resources;

- Ensuring, within its competence, the execution of anti-corruption measures.

This expanded list of objectives requires, in turn, a significant increase in the functions and powers of the Accounts Chamber.

The Accounts Chamber of the Russian Federation is endowed with 25 functions, and the list is open-ended. All the functions of the Accounts Chamber are important in view of achieving objectives. Some of them, in our opinion, should be mentioned specifically:

- To exercise external public financial control over the budget sphere; 
- To examine draft federal budget laws and draft laws on federal extra-budgetary funds for the next financial year and planning period, to examine and analyze the validity of the indicators, based on examination of draft laws on the federal budget and federal extra-budgetary funds, to prepare and submit conclusions to the chambers of the Federal Assembly of the Russian Federation;

- To exercise control over regional and local budgets, which are recipients of intrabudgetary transfers from the federal budget;

- To carry out operational performance analysis and control of the organization of the federal budget's execution in the current fiscal year;

- To conduct audits and specific inspections to examine the execution of individual sections (subsections), target items and types of expenditures of the federal budget and federal extra-budgetary funds at the location of inspected entities;

- To conduct auditing in the field of goods, works and services procurement undertaken by inspected entities, and other functions.

An important mechanism for ensuring the effectiveness of the Accounts Chamber as a body, which plays a key role in the implementation of parliamentary control, has become the provision requiring law enforcement agencies to provide information to the Accounts Chamber on the progress of consideration and decisions made on the relevant materials submitted to them by the Chamber.

Another interesting innovation is a norm, according to which, the Accounts Chamber of the Russian Federation, on the basis of enquiries from regional and municipal control and accounting bodies, regional legislative authorities and local self-governance institutions, conducts assessment (analysis) of the activity of these control and accounting institutions and provides an independent opinion on the compliance of the activity with the legislation on external public financial auditing, as well as preparing recommendations on the improvement of effectiveness.

The Accounts Chamber consists of the Chairman of the Accounts Chamber, the Deputy Chairman of the Accounts Chamber, auditors of the Accounts Chamber and the Office of the Accounts Chamber. To execute the vested powers, the Chairman of the Accounts Chamber issues orders and directives. Decisions of the Chairman of the Accounts Chamber and the Deputy Chairman of the Accounts Chamber can also be issued in the form of written orders (instructions).

Internal operational matters of the Accounts Chamber, the division of functions among the auditors of the Accounts Chamber, the content of the areas of works headed by the auditors of the Accounts Chamber, the functions of and interaction between the structural units of the office thereof and the procedures of operation are determined by the Regulations of the Accounts Chamber. The Regulations provide the legal basis for governing the procedural and internal operational matters of the Accounts Chamber. 
The Accounts Chamber independently develops and approves, in the established order, the standards of the Accounts Chamber - internal normative documents, defining the characteristics, rules and procedures of planning, organization and implementation of the various activities of the Chamber and (or) requirements resulting from the results of the activities. The Accounts Chamber works with two types of standards: activity arrangement standards and external public audit (control) standards.

Based on the results of the executed control measures, the Accounts Chamber has the right to deliver to public authorities, other state bodies and the heads of inspected organizations, representations for undertaking measures to eliminate revealed violations, to compensate the state for damage done and to take legal steps against officials found to be violating the legislation of the Russian Federation.

Should any breaches in the business, financial, commercial or other activity of the inspected entities be revealed in the process of control measures which cause damage to the state and, in connection with this, need to be immediately eliminated, as well as in cases of non-observance of the procedure and dates for consideration of representations of the Accounts Chamber, in cases of impeding control, expertise and analytical measures, the Accounts Chamber has the right to issue mandatory ordinances to the management of the inspected objects.

It is important that the improvement of financial control in Russia is based on the clearly defined principles set forth in compliance with international legal principles of independent auditing (control), in particular, those set out in the Lima Declaration.

\section{The Budget Code of the Russian Federation and the new approaches to public financial control}

According to the new wording of Section IX, Chapter 26 of the BC of RF "Principles of State and Municipal Financial Control", the mentioned types of control are conducted with the purpose of ensuring the observance of budget legislation of the Russian Federation and other normative legal acts, regulating public relations in the budget sector.

In conformity with the new classification, public financial control is subdivided into external and internal, preliminary and follow-up . All these forms of control are exercised by the state and municipal legislative (representative) bodies at the federal, regional and local levels.

The legislator defines external public financial control in the budget sphere as a control activity of the Accounts Chamber, regional control and accounting institutions and municipal entities accordingly, that is the control conducted by the bodies of external public financial control. 
In turn, internal public financial control in the budget sphere is a control activity of the Federal Service of Financial and Budgetary Supervision and public financial control institutions.

Accordingly, at the regional level, internal control is exercised by the regional executive bodies and local administrations. They all are bodies of internal public financial control, including the Federal Treasury and financial bodies ${ }^{12}$ of the constituent entities of the Russian Federation and municipal entities.

Preliminary control is exercised with the purpose of preventing and restraining violations in the course of execution of a budget of the budgetary system of the Russian Federation $^{13}$ (this definition resembles the concept of current financial control).

The previous wording of Part IX of the BC of RF provided for the exercising of preliminary control at the stage of discussion and approval of draft laws or decisions on the budget and other draft laws or decisions on fiscal matters that corresponded to the essence of this form of control.

Preliminary financial control should be conducted prior to the adoption of administrative decisions which are important for the prevention of financial violations. It prescribes assessment of the financial soundness of budget indicators with the purpose of preventing the wasteful and inefficient spending of budgetary funds.

Follow-up control is carried out based on the results of the budget's execution in order to ascertain the legitimacy of its performance and the reliability of accounting and reporting. In this case the concept of subsequent control is substantial, and the norm itself appears to be comprehensive and reflects the objectives of the budgetary legislation.

The new wording of the reviewed section provides for a clear definition of the control elements and mechanisms for the implementation of control powers. This applies, for example, to the concept of entities subject to public control. The drawback of norms on the entities subject to control is their definition through the simple listing of the entities with the establishment of terms under which they become subject to control.

So, the entities subject to control are financial bodies in terms of observance by them of the purposes and terms of granting inter-budgetary transfers and budget credits allocated from another budget of the budgetary system of the Russian Federation; adminis-

12 According to the BC of RF, financial bodies mean the Ministry of Finance of the Russian Federation and executive power bodies of constituent entities of the Russian Federation engaged in forming and arranging the administration of budgets of constituent entities of the Russian Federation (financial bodies of constituent entities of the Russian Federation), bodies (officials) of local administrations of municipal entities engaged in forming and arranging the administration of local budgets (financial bodies of municipal entities).

13 According to the $\mathrm{BC}$ of RF, the budgetary system of the Russian Federation means the totality of the federal budget, budgets of constituent entities of the Russian Federation, local budgets and budgets of state extra-budgetary funds, based on economic relations and the state structure of the Russian Federation and regulated by rules of law. 
tration bodies of the federal extra-budgetary funds; legal entities-recipients of resources of the federal extra-budgetary funds for financing obligatory medical insurance; lending agencies carrying out certain operations with budgetary resources in terms of their compliance with agreements (contracts) on resources allocation from the respective budget of the Russian budgetary system; public (municipal) institutions; state (municipal) unitary enterprises; state corporations, companies etc.

Thus, entities subject to control are recipients of budget resources, while Russian financial law determined the totality of public funds, both budgetary and extra-budgetary, as subject to control. In turn, the recipients of budgetary funds were considered as controlled entities of the state and municipal financial control. Unfortunately, there are certain differences between the approaches of the scholarly community and the legislation in the understanding of the elements of control. It is obvious that the appropriate legal regulation is a prerequisite of the effective execution of public financial control.

Another important and required element of control is the method of its implementation, which was understood as techniques and procedures for exercising financial control.

The new wording of the respective section and the chapter of the $\mathrm{BC}$ of $\mathrm{RF}$ on public financial control refers inspection, auditing, surveying and authorization to operate to the methods of public financial control. For the first time the $\mathrm{BC}$ of RF provides not only a list of methods, but their definitions as well.

The Federal Law "On the Accounts Chamber of the Russian Federation" determines inspection, auditing, analysis, surveying and monitoring as the methods of control and expert and analytical activity. As we can see, the Accounts Chamber of the Russian Federation applies relatively new methods in Russian legal practice, which are analysis and monitoring that correspond to the controlling powers of the Accounts Chamber.

Inspection refers to the performance of control actions with regard to the activity of an entity during a certain period, including documentary and actual examination of financial and economic operations for legality, budget accounting and budget reporting for reliability. Inspections can be divided into cameral and field (on-site), including cross-examination inspections. The same is applied in exercising tax checks in compliance with the Tax Code of the Russian Federation. Apparently, such structuring of inspection was perceived by Russian lawmakers based on the positive experience of tax bodies in the area of performing tax control.

According to Chapter 26 of the $\mathrm{BC}$ of RF, a cameral inspection is an examination conducted in the office of the public financial control body based on budgetary (accounting) statements and other documents received under its request. Field checks shall be conducted at the location of an audited entity with the purpose of examining performed operations for correspondence with the data of budgetary (accounting) statements and bookkeeping entries . 
Cross-examination inspections shall be conducted within the framework of field and (or) cameral inspections to ascertain and (or) confirm facts related to the activity of the audited entity.

Chapter 26 of the $\mathrm{BC}$ of RF defines an audit as a comprehensive inspection of an entity, including the performance of control actions such as documentary and actual examination of the entirety of the financial and economic operations for legality and the correct recognition thereof in the entity's accounting book and budgetary reporting. Results of inspections and audits are documented in the form of an audit certificate. The audit is generally performed with a view to checking the legality of using resources allocated from the budget.

A Survey, for the aims of the BC of RF, refers to analysis and assessment of the status of a certain type of activity of an entity subject to control. The results of surveys are documented as final reports.

Authorization to operate refers to an endorsement which is made after examination of documents submitted for the purpose of financial operations to confirm that the aforementioned documents exist and (or) contain information that meets the requirements set forth in the budget legislation of the Russian Federation and other normative acts regulating budgetary legal relations.

The reviewed chapter of the $\mathrm{BC}$ of $\mathrm{RF}$ determines the powers vested in external public financial control institutions to exercise external public financial control. Article 268.1 of the $\mathrm{BC}$ of $\mathrm{RF}$ refers to inspections, audits and surveys as methods of control which only partially conform with the provisions of the Federal Law "On the Accounts Chamber of the Russian Federation”.

However, Article 268.1 of BC of RF contains a norm, according to which, control in the areas not listed in the $\mathrm{BC}$ of $\mathrm{RF}$ shall be exercised by the institutions of external public financial control in compliance with the provisions of the Federal Law "On the Accounts Chamber of the Russian Federation" and the Federal Law "On General Principles of Organization and Activity of the Control and Accounting Institutions of the Constituent Entities of the Russian Federation and Municipal Entities", as well as regional laws and municipal legal acts of representative bodies of municipal entities.

Article 269.1 of the BC of RF determines the authority of the Federal Treasury. The Federal Treasury (the Treasury of Russia) is a federal executive body (federal service) responsible for exercising, in accordance with Russian legislation, law-enforcement functions to ensure implementation of the federal budget, providing cash for the implementation of other budgets of the Russian budgetary system, conducting preliminary and current control of transactions involving federal budget funds by chief administrators, administrators and recipients of federal budget funds.

The powers of the Federal Treasury in the area of control are significant and specific. It shall exercise control to ensure that: operations with federal budget resources do not 
exceed the approved limits of budget obligations and (or) budgetary appropriations; the content of an operation being conducted matches the code of the budgetary classification of the Russian Federation stated in the payment document submitted to the Federal Treasury by the recipient of the federal budgetary resources; documents confirming the occurrence of monetary obligations payable by the budgetary funds are available.

The same chapter of the BC RF was amended by the article on representations and ordinances of public financial control institutions, which are the documents to be prepared and forwarded based on the results of control and in instances when violations of the budget legislation of the Russian Federation and financial discipline were revealed.

\section{Conclusion}

According to the Russian legislator and representatives of controlling and financial agencies, most cases of abuse related to the use of budgetary funds occur at the stage of order placement for procurement of goods, works and services for public and municipal needs at the expense of budgetary and extra-budgetary funds. Order placement in Russia is carried out through the organization of competitive bidding in the form of a tender or an auction, including those organized in electronic form, and without competitive bidding (by a quotations request, through a single supplier (executor, contractor), through trade exchanges). The Federal Law of July 21, 2005, No. 94-FZ "On Placement of Orders to Supply Goods, Carry out Works and Render Services for Meeting State and Municipal Needs" regulated relations associated with the procurement of goods, works and services for the state and municipal needs, and the needs of budget-funded organizations. The given law is to be abolished on January 1, 2014 in connection with the adoption of the new Federal Law of April 5, 2013 "On the Contract System in the Sphere of Goods, Works and Services Procurement for the State and Municipal Needs" (comes into force on January 1,2014). The state lays its high hopes on the new law. Along with the new laws on state financial control, as suggested by the Russian Parliament and the Government, it will support the solving of systemic problems, and most importantly, restrain corruption and all kinds of criminal schemes, designed by the representatives of public authorities and officials for misappropriating budgetary resources. The Federal Law of April 5, 2013 "On the Contract System in the Sphere of Goods, Works and Services Procurement for the State and Municipal Needs" is aimed at ensuring the publicity and transparency of the public procurement process, preventing corruption and other abuses in the sphere of the procurement of goods, works and services.

Russian society, the active part of which is called civil society, expects and hopes for the effectiveness of the contract system. What is required from the leaders of the state, is the political will and a strong focus on handling by means of law the problems accumu- 
lated in the financial sphere. The state must rely on political parties, public associations of citizens and the whole of Russian society, the people, to effectively resolve Russia's painful problems. The main goal of the adopted federal laws is the prevention of budgetary violations by means of countering corruption, accomplishment of which will depend on the effective work of external and internal public control. One of the essential tasks of the state is to promote the development of public control.

\section{SUMMARY}

\section{The novelties in the legislation of the Russian Federation on public financial control}

The article studies the new legislation of the Russian Federation on public financial control. The author justifies the idea of reforming financial control through the need to fight corruption, which has obtained a warning scale in Russia and threatens the state's foundations. The article contains an analysis of the powers vested in external and internal state financial control institutions, of entities subject to control and methods of control. The author notes that representations and ordinances issued by control and accounting institutions, based on the results of control activities, are designed to force the violators of financial discipline to eliminate the revealed violations. The author concludes that the necessary condition for effective implementation of public financial control is its clear legal regulation. The article stresses that the improvement in financial control in Russia is based on clearly stated principles, in accordance with international legal principles of independent auditing (control).

Keywords: budget legislation, state financial control, public financial control, the Accounts Chamber of the Russian Federation. 
278 | Adam Mickiewicz University Law Review 